報 告

\title{
足立区における学童心臟検診について
}

Mass Examination of Cardiac Disorders in

School Children of Adachi-district

井埜利博* 岩原正純* 西本㤵*

Toshiniro INO, M. D. Masazumi IWAHARA, M. D. Kei Nishimoto, M. D.

秋元 かつみ* 藪田敬次 郎*

Katsumi AKIMOTO, M. D. \& Keijiro YABUTA, M. D.

近年, 学校心臟検診は厚生省研究班の努力により 各地で極めてめざましい普及をとげた。その目的 は見逃されていた心疾患児を早期に発見し，適切 な治療および管理により突然死を予防し，安全な 学校生活をおくらせることにある。東京都におい ても東京都予防医学協会により学童心臟検診か昭 和43年より開始され学校保健の上で極めて重要な 投割りを担っている1-2)。そのシステムはアンケー $卜$, 校医聴診, 心音図, 心電四, 胸部 $X$ 線, 専門
医の聴診および心エコー図などの組み合せによる 選別方式と全員心音・心電龱方式の 2 方法により 行われている(図 1)。私どもは順天堂大学膠原病 内科の村上正中教授の後に引き続いて昭和 55 年よ り足立区の心臟検診に参加している。 今回は足立 区心臟検診を始めてから約 10 年を経過したので, その間に経験した症例のうち学校保健の上でも重 要と思的る症例を呈示し, 足立区に㧍ける全員 心音・心電図方式の利点について述べる。

\section{全員心音 ·心電図方式}

\begin{tabular}{|c|c|}
\hline \multicolumn{2}{|l|}{1 次検診 } \\
\hline 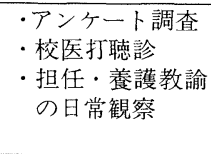 & $\begin{array}{l}\text { ·簡略誘導心音・ } \\
\text { 心電困 } \\
\text { 心音図 }(2 \mathrm{LS}, \\
\text { 4LS) } \\
\text { 心電闵 } \mathrm{I}, \mathrm{V}_{\mathrm{a}}, \mathrm{V}_{1}, \mathrm{~V}_{6}\end{array}$ \\
\hline 校医 教師 & 東京都予防医学協会 \\
\hline
\end{tabular}



選 別 方 式

\begin{tabular}{|c|c|c|c|c|}
\hline 1 次 検 診 & 2 次 検 診 & 3 次 検 診 & & 管 理 \\
\hline $\begin{array}{l}\text { ·アンケート調査 } \\
\text { ·校医打聴㟝 } \\
\text { ·担任·養護教諭の } \\
\text { 日常観察 }\end{array}$ & $\begin{array}{l}\text { ·簡略誘導心音・ } \\
\text { 心電図 } \\
\text { 心音図 }(2 \mathrm{LS}, \\
4 \mathrm{LS})\end{array}$ & $\begin{array}{l}\text { ·専門医診察 } \\
\text { ·標準 } 12 \text { 誘導心電困 } \\
\text { · 心音図 } \\
\text { · その他の必要な検査 }\end{array}$ & \begin{tabular}{|l} 
総合判定 \\
曺門 医
\end{tabular} & $\begin{array}{l}\text { · 医療分類 } \\
\text { - 予防分類 } \\
\text { · 管理分類 } \\
\text { · 生活分類 }\end{array}$ \\
\hline $\begin{array}{l}\text { 校医 教師 } \\
\text { 東京都子防医学協会 }\end{array}$ & $\begin{array}{l}\text { 心電図 } I_{,}, V_{\mathrm{F}}, V_{1}, L_{6} \\
\text { - 胸部 } \mathrm{X} \text { 線間接撮影 }\end{array}$ & $\begin{array}{l}\text { 専門医 } \\
\text { 東京都子防医学協会 }\end{array}$ & & 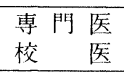 \\
\hline
\end{tabular}
東京都予防医学協会

図 1 東京都における学童心臟検診システム

\section{* 順天堂大学医学部小児科学教室}

Department of Pediatrics, Juntendo University School of Medicine.

(March 23，1985受付)

\section{足立区における心臓検診システムと 10 年間の動態}

対象は小学校入学時および中学校入学時の学童 
保護者の皆きんん

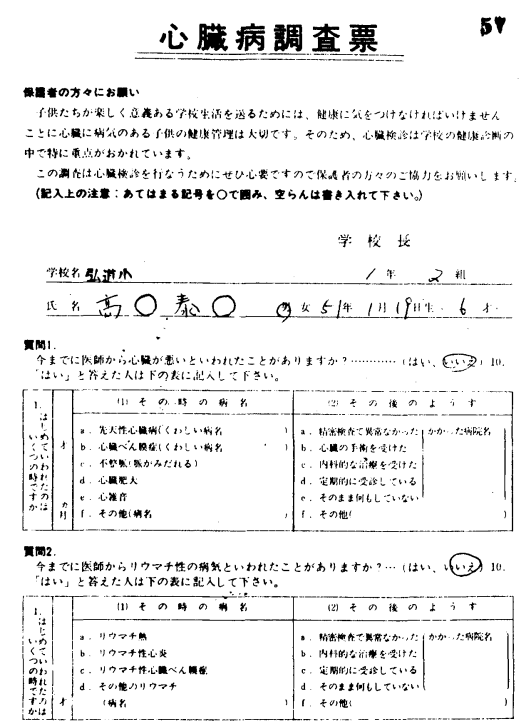

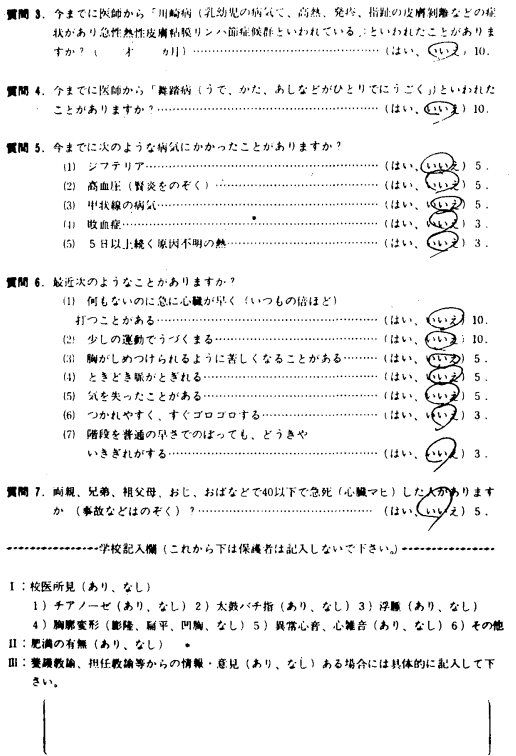

困 2 学童心臓検診のアンケート

全員である、家族からのアンケート（図 2 ) およ U゙省略心電図 $\left(I, a V F, V_{1} V_{6}\right.$ ), 省略心音図(胸骨左 縁第 2 ，第 4 肋間）により一次検診異常者として 抽出される。一次検診の異常者は二次検診にて専 門医の聴診，12誘導心電困（時に診察した専門医 により必要であれば適宜負荷心電図を行う.)胸部 X線（川崎病既往者は正側面で撮影する。）により 専門病院での精查, 治療および管理の必要性につ いて検討される（図 1 ).

過去 10 年間の動態をみると年間の総受検者数は 小学生では約 8,000 名 12,000 名であり, 53 年度よ り年々減少傾向にある。一方，中学生では約 7,000 名〜 11,000 名であり年々増加傾向にあったが，昭 和57年度はやや減少している。今後は小学生数の 動態を考えると中学生の受検者数は減少して行く ものと思われる。それらのうち有所見者は小学生 では全体の 0.37 1.69\%（平均 $0.65 \%$ ）で，中学 生では0.35 2.17\% (平均 $0.87 \%$ ) である. 他地 区での平均值に比しやや低い傾向にある。昭和56 年度以後, 有所見者数が急激に増加している理由 は主に不整脈患児の増加によるものと思われる。 すなわち以前では管理不要としていた単発の上室
性および心室性期外収縮は, 最近では負荷心電龱 あるいは Holter 心電図などにより心房粗・細動 心室性頻拍症が発見される症例が報告されており 管理を要するとしたためと思われる（表 1).

小・中学生の有所見者の内訳は先天性心疾患約 $0.3 \%$, 後天性心疾患 $0.01 \sim 0.02 \%$ および不整脈 0.2 0.4\%である。これらは東京都における他地 区の頻度とほぼ類似している，先天性心疾患では 小学校, 中学校ともに心室中隔欠損症 (VSD), 心 房中隔欠損症 (ASD), 肺動脈狭窄症 (PS) およ びファロー四徵症（TOF）の順である。中学生で はASDの頻度がやや高いようである。後天性心 疾患のほとんどが僧帽弁閉鎖不全症（MI）あるい は大動脈弁閉鎖不全症（AI）であり，特に中学生 では後天性心疾患の約 $1 / 3$ が MI である。当然のこ とながら川崎病冠動脈瘤をもつ患児がこの中に含 まれている，心電図異常は期外収縮，脚ブロック WPW 症候群の順に多く，3者でその大半をしめ る(表 $2 ， 3$ )。著者らの印象では，前記した疾 患より“その他”の欄に含まれるもの（例之ば完 全房室ブロック，心室性頻拍症，QT 延長症候群 特発性心筋症および川崎病冠動脈瘤など）がむし 
表 1 心疾患受診集計表

\section{足立区小学校 1 年生}

\begin{tabular}{|c|c|c|c|c|c|c|c|c|c|c|c|c|c|}
\hline \multirow{3}{*}{$\begin{array}{c}\begin{array}{c}\text { 年 度 } \\
\text { (昭和) }\end{array} \\
48\end{array}$} & \multirow{3}{*}{$\frac{\mid \text { 受坽首数 }}{9,843}$} & \multirow{2}{*}{\multicolumn{2}{|c|}{  }} & \multirow{2}{*}{\multicolumn{4}{|c|}{ 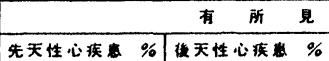 }} & 者 & \multicolumn{3}{|l|}{ VR } & \multirow{2}{*}{\multicolumn{2}{|c|}{ もの地の所見 \% }} \\
\hline & & & & & & & & \multicolumn{2}{|c|}{ その他の心珻惠 \% } & \multicolumn{2}{|c|}{ 心五因常常 \% } & & \\
\hline & & $68(1)$ & 0.69 & 36 & 0.36 & & & & & 33 & 0.33 & & \\
\hline 49 & 11.754 & $48(2)$ & 0.41 & 39 & 0.33 & 2 & 0.01 & 5 & 0.04 & 4 & 0.03 & 2 & 0.02 \\
\hline 50 & 11,755 & 60 & 0.51 & 30 & 0.26 & 1 & 0.01 & 6 & 0.05 & 23 & 0.19 & 1 & 0.01 \\
\hline 51 & 11.402 & $42(1)$ & 0.37 & 30 & 0.26 & 1 & 0.01 & 10 & 0.09 & 2 & 0.01 & 2 & 0.01 \\
\hline 52 & 11.624 & $46(2)$ & 0.39 & 40 & 0.34 & 2 & 0.01 & 3 & 0.02 & 3 & 0.02 & 1 & 0.01 \\
\hline 53 & 11.729 & $45(2)$ & 0.38 & 40 & 0.33 & & & 3 & 0.02 & 4 & 0.03 & 3 & 0.02 \\
\hline 54 & 11,412 & $47(1)$ & 0.41 & 36 & 0.31 & 1 & 0.01 & 2 & 0.01 & 9 & 0.08 & 2 & 0.01 \\
\hline 55 & 10.697 & $69(2)$ & 0.65 & 43 & 0.39 & 2 & 0.01 & 21 & 0.19 & 7 & 0.06 & 3 & 0.02 \\
\hline 56 & 9,853 & $130(4)$ & 1.32 & 47 & 0.46 & 2 & 0.02 & 16 & 0.16 & 69 & 0.68 & 15 & 0.15 \\
\hline 57 & 8.692 & $147(3)$ & 1.69 & 50 & 0.56 & 1 & 0.01 & 19 & 0.21 & 80 & 0.91 & 17 & 0.19 \\
\hline 合 it & 108.761 & $707(18)$ & 0.65 & 391 & 0.35 & 12 & 0.01 & 85 & 0.07 & 234 & 0.22 & 46 & 0.04 \\
\hline
\end{tabular}

\section{足立区中学校 1 年生}

\begin{tabular}{|c|c|c|c|c|c|c|c|c|c|c|c|c|c|}
\hline \multirow{3}{*}{$\begin{array}{c}\begin{array}{l}\text { 年 度 } \\
\text { (昭和) }\end{array} \\
48\end{array}$} & \multirow{3}{*}{ 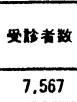 } & \multirow{2}{*}{\multicolumn{2}{|c|}{$\begin{array}{c}\text { 有所胃者数 } \\
\text { (合併遮) \% }\end{array}$}} & \multirow{2}{*}{\multicolumn{4}{|c|}{ 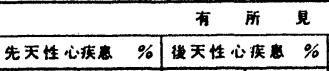 }} & * & UR & & & \multirow{2}{*}{\multicolumn{2}{|c|}{ 七の他の邱見 \% }} \\
\hline & & & & & & & & \multicolumn{2}{|c|}{ 安の他の心疾室 \% } & \multicolumn{2}{|c|}{ 心国珙常\% } & & \\
\hline & & 62 & 0.82 & 27 & 0.36 & 4 & 0.05 & & & 31 & 0.41 & & \\
\hline 49 & 7.992 & 29 & 0.36 & 21 & 0.26 & & & 2 & 0.02 & 6 & 0.05 & 1 & 0.01 \\
\hline 50 & 8.372 & 48 & 0.57 & 17 & 0.20 & 1 & 0.01 & 6 & 0.07 & 24 & 0.29 & 2 & 0.02 \\
\hline 51 & 8.824 & $37(1)$ & 0.42 & 17 & 0.19 & 1 & 0.01 & 18 & 0.20 & 2 & 0.02 & & \\
\hline 52 & 9.721 & $35(2)$ & 0.35 & 26 & 0.25 & 3 & 0.03 & 7 & 0.06 & 1 & 0.01 & & \\
\hline 53 & 9.912 & $52(2)$ & 0.52 & 38 & 0.37 & 4 & 0.04 & 7 & 0.06 & 6 & 0.05 & & \\
\hline 54 & 9.039 & $54(1)$ & 0.60 & 29 & 0.32 & & & 16 & 0.17 & 10 & 0.11 & & \\
\hline 55 & 10.627 & $77(2)$ & 0.72 & 35 & 0.33 & 4 & 0.03 & 20 & 0.18 & 20 & 0.18 & 6 & 0.06 \\
\hline 56 & 10.651 & 189 & 1.77 & 36 & 0.34 & 4 & 0.03 & 28 & 0.26 & 121 & 1.14 & 22 & 0.21 \\
\hline 57 & 10.215 & $222(1)$ & 2.17 & 39 & 0.38 & 1 & 0.01 & 42 & 0.41 & 141 & 1.37 & 21 & 0.21 \\
\hline 合 if & 92.920 & $805(9)$ & 0.87 & 285 & 0.31 & 22 & 0.02 & 146 & 0.15 & 362 & 0.39 & 52 & 0.06 \\
\hline
\end{tabular}

表 2 心疾患別診断結果集計及び異常内訳(1)

足立区小学校 1 年生

\begin{tabular}{|c|c|c|c|c|c|c|c|c|c|c|c|c|c|c|c|c|c|c|}
\hline \multirow{2}{*}{ 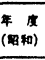 } & \multirow[b]{2}{*}{ VSDC } & \multicolumn{8}{|c|}{ 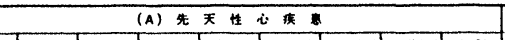 } & \multicolumn{4}{|c|}{ 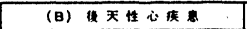 } & \multicolumn{4}{|c|}{ (c) *の电の心 } & \multirow{2}{*}{$\mid \begin{array}{c}A+B+C \\
8 \\
1\end{array}$} \\
\hline & & $\sqrt{A S D(1)}$ & PDAC & PSI & $T / F()$ & AS( ) & JECDI & 痤onter & 小H & MIC & All & Fonet (1) & 小形 & 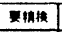 & 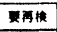 & \begin{tabular}{|l|} 
†の他 \\
\end{tabular} & wH & \\
\hline 48 & $22(3)$ & $7(1)$ & (0) & $6(0)$ & $1(1)$ & & & & $36(5)$ & & & & & & & & & $36(5)$ \\
\hline 49 & $22(2)$ & $4(0)$ & $2(1)$ & $3(1)$ & $5(4)$ & & & 3 & $39(8)$ & & 2 & & 2 & 11 & 1 & & 5 & $46(8)$ \\
\hline 50 & $12(2)$ & $8(3)$ & $2(2)$ & $4(3)$ & $4(1)$ & & & & $30(11)$ & 1 & & & 1 & 1 & 2 & 3 & 6 & $37(11)$ \\
\hline 51 & $18(4)$ & $1(0)$ & $2(1)$ & $4(1)$ & $1(1)$ & & & 4 & $30(7)$ & & & $1(1)$ & T(1) & 2 & 8 & & 10 & $41(8)$ \\
\hline 52 & $22(6)$ & $7(2)$ & $1(1)$ & $4(1)$ & $3(2)$ & & & 3 & $40(11)$ & $2(1)$ & & & $2(1)$ & & 1 & 2 & 3 & $45(12)$ \\
\hline 53 & $26(3)$ & $3(1)$ & $2(2)$ & I(1) & $2(2)$ & 1 & & $5(3)$ & $40(12)$ & & & & & & & $3(2)$ & $3(2)$ & $43(14)$ \\
\hline 54 & $17(2)$ & $6(3)$ & $2(1)$ & $2(1)$ & $6(6)$ & 2 & & 1 & $36(13)$ & 1 & & & 1 & 1 & & 1 & 2 & $39(13)$ \\
\hline 55 & $19(4)$ & $7(6)$ & $3(3)$ & $3(0)$ & $2(2)$ & 1 & & $8(2)$ & $43(17)$ & 1 & & $1(1)$ & $2(1)$ & 3 & 12 & 6 & 21 & $60(18)$ \\
\hline 56 & $25(5)$ & $4(2)$ & i(1) & $6(1)$ & $4(3)$ & $2(1)$ & & $5(3)$ & $47(16)$ & 1 & & 1 & 2 & 2 & 8 & 6 & 16 & $65(16)$ \\
\hline 57 & $23(7)$ & $10(4)$ & $1(0)$ & $1(0)$ & $5(5)$ & & & $10(5)$ & 50(21) & & & 1 & 1 & 1 & 9 & 9 & 19 & $70(71)$ \\
\hline $8 \mathrm{H}$ & $206(37)$ & $57(22)$ & $16(12)$ & $34(9)$ & $33(27)$ & $6(1)$ & & $39(13)$ & $391(121)$ & $6(1)$ & 2 & $4(2)$ & $12(3)$ & 14 & 41 & $30(2)$ & $85(2)$ & $488(126)$ \\
\hline
\end{tabular}

\begin{tabular}{|c|c|c|c|c|c|c|c|c|c|c|c|c|c|c|c|c|c|c|}
\hline \multirow{2}{*}{ 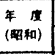 } & \multicolumn{9}{|c|}{ (A) 先天性的莫 } & \multicolumn{4}{|c|}{  } & \multicolumn{4}{|c|}{ (c) もの他の心 } & \multirow{2}{*}{\begin{tabular}{|c|c}
$A+B+C$ \\
8 \\
1
\end{tabular}} \\
\hline & vsor & ASD ( ) & IPDAC & PS( ) & $T / F()$ & AS( ) & $E C D()$ & Fontiti & 小时 & MII & All () & Font & 小站 & 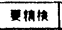 & 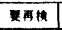 & †の他 & 小胡 & \\
\hline 48 & $8(2)$ & $12(1)$ & $(1)$ & in) & $1(1)$ & & & $5(1)$ & $27(4)$ & 4 & & & 4 & & & & & $311(4)$ \\
\hline 49 & $7(1)$ & $2(2)$ & (3) & $5(3)$ & (1) & & $1(1)$ & & $21(7)$ & & & & & 2 & & & 2 & $23(7)$ \\
\hline 50 & 4() & $4(2)$ & 3() & 3() & $1(1)$ & & $1(1)$ & 1 & $17(7)$ & & & & 1 & 1 & 4 & 1 & 6 & $24(7)$ \\
\hline 51 & IIII) & $4(1)$ & il) & (1) & $1(1)$ & & & & $17(3)$ & & 1 & & 1 & 2 & 14 & 2 & 18 & $36(3)$ \\
\hline 52 & $14(2)$ & 3() & (1) & $4(1)$ & $3(2)$ & & (1) & 1 & $26(6)$ & 3 & & & 3 & 2 & 5 & & 7 & $36(6)$ \\
\hline 53 & $n(6)$ & $12(1)$ & i(1) & $3(2)$ & $(1)$ & 1 & I(1) & $3(2)$ & $38(13)$ & 2 & & 2 & 11 & 5 & & 2 & 7 & 19(13) \\
\hline 54 & $16(3)$ & $6(2)$ & ( ) & 4() & $2(2)$ & & & $1(1)$ & $29(8)$ & & & & & 11 & 2 & 3 & 16 & 45(8) \\
\hline 55 & $17(4)$ & $5(1)$ & () & $8(5)$ & $3(3)$ & & & $2(1)$ & $35(14)$ & 2 & & 2 & 4 & 2 & 10 & $8(1)$ & $20(1)$ & $50(15)$ \\
\hline 56 & $12(3)$ & $12(7)$ & $3(3)$ & $2(1)$ & $5(4)$ & & & $2(1)$ & $36(19)$ & $2(1)$ & & 2 & $4(1)$ & 2 & 18 & 8 & 28 & $68(20)$ \\
\hline 57 & $12(4)$ & $9(3)$ & $2(2)$ & $3(2)$ & $1(1)$ & & & $6(4)$ & $39(16)$ & 1 & 1 & & 1 & 1 & 21 & 20 & 12 & $22(10)$ \\
\hline $8 \mathrm{H}$ & $124(76)$ & $75(19)$ & $10(10)$ & $33(14)$ & $17(14)$ & 1 & $4(4)$ & $21(10)$ & $285(97)$ & $14(1)$ & 2 & 6 & $22(1)$ & 28 & 14 & $41(1)$ & $1466(1)$ & $453(22)$ \\
\hline
\end{tabular}


表 3 心疾患別診断結果集計及び異常内訳(2)

足立区小学校 1 年生

\begin{tabular}{|c|c|c|c|c|c|c|c|c|c|c|c|c|c|c|c|c|c|c|}
\hline \multirow{3}{*}{ 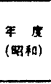 } & \multicolumn{16}{|c|}{$(0)$ i $=$ 圆 } & \multirow{3}{*}{ 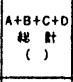 } & \multirow{3}{*}{ 合俸相 } \\
\hline & \multicolumn{3}{|c|}{ Mフロック } & \multicolumn{3}{|c|}{ 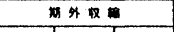 } & \multicolumn{3}{|c|}{  } & \multicolumn{3}{|c|}{$\pi \quad t$} & \multirow{2}{*}{ WPW } & \multirow{2}{*}{ 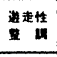 } & \multirow{2}{*}{ *の化 } & \multirow{2}{*}{ 小 } & & \\
\hline & 先金右 & 不完全右 & 无の他 & i正性 & 上圭性 & †の他 & $1 \pi$ & 11 & *の他 & t E & 右 & 弗他 & & & & & & \\
\hline 48 & 7 & 8 & & 7 & 5 & & & & & & & & 6 & & & 33 & $69(5)$ & 1 \\
\hline 49 & & & & & & 1 & & & & & & & 3 & & & 4 & $50(8)$ & 2 \\
\hline 50 & 6 & 3 & & 2 & 1 & 3 & & & & & & & 8 & & & 23 & $60(11)$ & \\
\hline 51 & & & & & 1 & & & & & & & & 1 & & & 2 & $43(8)$ & 1 \\
\hline 52 & & 1 & & & & & & & & & & & 1 & & 1 & 3 & $48(12)$ & 2 \\
\hline 53 & 1 & & & & & & & & & & & & 2 & & 1 & 4 & $47(14)$ & 2 \\
\hline 54 & 1 & & & 1 & & & & & & & & & 4 & & 3 & 9 & $48(13)$ & 1 \\
\hline 55 & & & 1 & 3 & & & & & & & 1 & & 2 & & & 7 & $73(18)$ & 2 \\
\hline 56 & 3 & 5 & 2 & 19 & & 11 & & 1 & & 1 & & & 3 & & 24 & 69 & $134(16)$ & 4 \\
\hline 57 & 3 & 5 & 6 & 17 & 2 & 14 & 4 & & & 1 & 1 & & 3 & 4 & 20 & 80 & $150(21)$ & 3 \\
\hline 會 & 21 & 22 & 9 & 49 & 9 & 29 & 4 & 1 & & 2 & 2 & & 33 & 4 & 19 & 214 & $722(126)$ & 18 \\
\hline
\end{tabular}

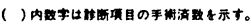

足立区中学 1 年生

\begin{tabular}{|c|c|c|c|c|c|c|c|c|c|c|c|c|c|c|c|c|c|c|}
\hline \multirow{3}{*}{ 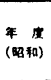 } & \multicolumn{15}{|c|}{$(D)$ is $=0$} & \multirow{3}{*}{ 小 H } & \multirow{3}{*}{$\mid \begin{array}{c}A+B+C+D \\
2 \\
1\end{array}$} & \multirow{3}{*}{ 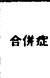 } \\
\hline & \multicolumn{3}{|c|}{ พプック } & \multicolumn{3}{|c|}{ 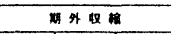 } & \multicolumn{3}{|c|}{ 周チロック } & \multicolumn{3}{|c|}{ 㴔 } & \multirow{2}{*}{ WPW } & \multirow{2}{*}{ 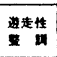 } & \multirow{2}{*}{ *の他 } & & & \\
\hline & 党全右 & 不宪全右 & *の他 & i五性 & 上弃性 & その他 & $1 \%$ & $11 t$ & †の他 & 在率 & 右和 & †の他 & & & & & & \\
\hline 48 & 3 & 7 & & 12 & 5 & & & & & & & & 4 & & & 31 & $62(4)$ & \\
\hline 49 & & & & & & & & & & & & & 6 & & & 6 & $29(7)$ & \\
\hline 50 & 6 & & & 9 & 2 & 1 & 1 & & & & & & 5 & & & 24 & $48(7)$ & \\
\hline 51 & & & & & & & & & & & & & 1 & & 1 & 2 & $38(3)$ & 1 \\
\hline 52 & 1 & & & & & & & & & & & & & & & 1 & $37(6)$ & 2 \\
\hline 53 & & & & & & & & & & & & & 4 & & 2 & 6 & $65(13)$ & 2 \\
\hline 54 & & & & 1 & & & & & & & & & 7 & & 2 & 10 & $55(8)$ & 1 \\
\hline 55 & 1 & 4 & & 10 & & & & & & & & & 2 & & 3 & 20 & $79(15)$ & 2 \\
\hline 56 & 5 & 9 & 2 & 15 & & 16 & 5 & 4 & 1 & & & & 11 & & 23 & 121 & $139(20)$ & \\
\hline 57 & 5 & 5 & 7 & 12 & 2 & 19 & 14 & 2 & 4 & 4 & & & 9 & 3 & 25 & 141 & $223(16)$ & 1 \\
\hline 今 H & 21 & 25 & 9 & 119 & 9 & 36 & 20 & 6 & 5 & 4 & & & 19 & 3 & 56 & 362 & $815(99)$ & 9 \\
\hline
\end{tabular}



ろ突然死と関係する疾患が多いように思われる.

しかし，それらの疾患は自覚症状のないことが多 く，選別方式で抽出することは極好て困難である。 以下に著者らが経験した㧍そらくは選別方式で は抽出されなかったであろう疾患について触れて みたい。

\section{症例}

症例 $1 ：$ N. W., 11歳, 女児

生来元気であり，失神発作の既往はない。学 校入学時の集団心臟検診にて心電図異常を指摘さ れたが，放置されていた。今回，昭和56年度の心 臓検診で完全房室ブロックを発見され精査のた め入院した。入院時の現症では軽度の徐脈を認め た以外に特記すべき所見はなく，また血液・尿検 查などの入院時一般検査でも異常を認めなかった。 心電図は心拍数55 60/分の完全房室ブロックを 認め, QRS 間隔は 0.04 秒であり，マスター 2 段負 荷心電図により散発性の心室性期外収縮を認めた
(図 3 ). 胸部 X線はCTR $=0.53$ と心拡大はなく, 肺野も正常であった。心臟超音波検査では器質的 な心疾患を疑わせる所見はなかった。入院後に行 つた His 束心電図では $\mathrm{AH}$ 時間の延長を認め $\mathrm{AH}$ ブロックとして現在心臟病管理区分表の $3 \mathrm{C}$
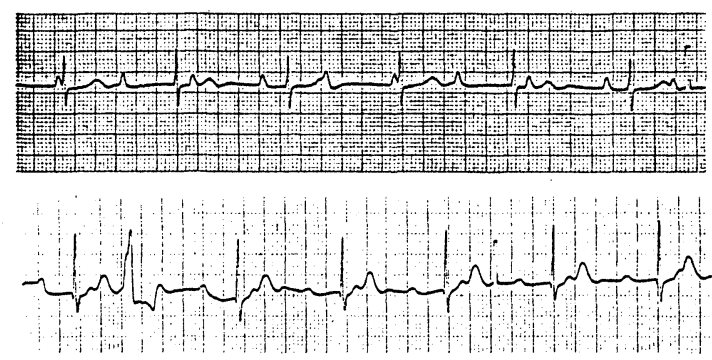

図 3 ECG N. W. 11y/o. Female 上段: 安静時 下段: 負荷心電困 QRS 間隔 0.04 秒，PP間隔0.6秒，RR 間隔 1.10 秒の完全房室ブロックを認め, マスター 2 段負荷心電困で散発性の心室性期外収縮を 認めた。 


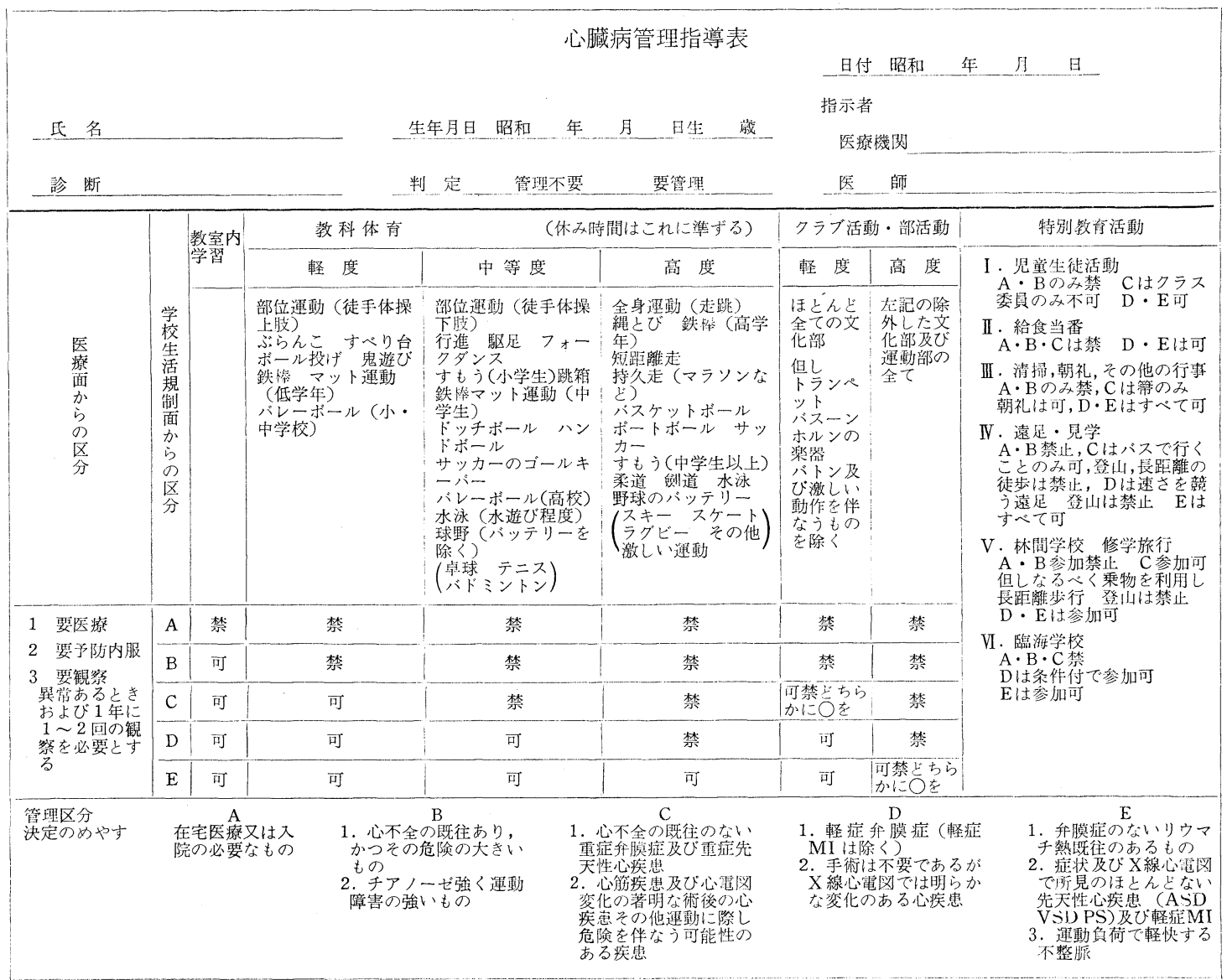

困 4 心臓病管理指導表（新らしいモデル）

可として経過観察している (困 4).

この症例は $\mathrm{AH}$ ブロックであり，おそらくは先 天性の完全房室ブロックと考えられる.心拍数が 比較的多いために見逃されていたものと思われる。 症例 2 : U. M., 12歳, 女児

生来健康であり，特記すべき既往歴はない。昭 和57年度の中学校入学時の集时心臟検診で不整脈 を指摘され本院を受診した。検診時の心電四で心 房粗動と䓂断され，精査および治療のため入院し た。入院壯の!血液一般检查, 胸部X線および心臓 超音波検查では特に異常を淧女なかったため特発 性心房粗動と診断された。茹静時の心電汹では 3：1ないし 4：1の心房粗動を認めた（网 5). 入院後，ジゴキシン $0.04 \mathrm{mg} / \mathrm{kg} /$ 日㧍よびインデラ



困 5 Esophageal ECG Y.M. 12y/o. Female. $\mathrm{E}$ : 食道誘導

食道誘導を記録することにより，P波がはっ きりし，心房粗動であることがわかる。 


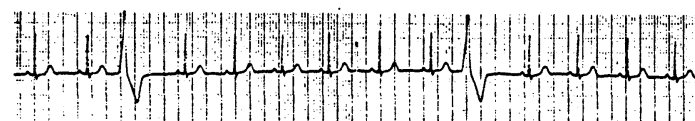



図 6 Holter ECG R. O. 6 y/o. Female. 上段：安静時心電図 下段：Holter 心電困 Holter 心電図では，時に心室性頻拍発作を認 めた。
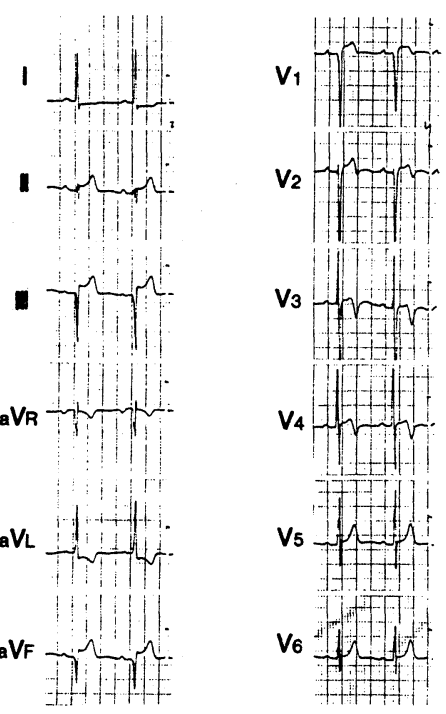

図 7 ECG W.I. 12y/o. Male.

I, ${ }_{a} \mathrm{~V}_{\mathrm{L}}$ の ST 低下, II. III, ${ }_{a} \mathrm{~V}_{\mathrm{F}} \mathrm{V}_{1-2}$ の ST 上 昇抢よびII.III, ${ }_{a} \mathrm{~V}_{\mathrm{F}} \mathrm{V}_{1}$ の異常 $\mathrm{Q}$ 波を認め心筋 障害を思わせた。

一ル $1 \mathrm{mg} / \mathrm{kg} /$ 日の併用療法で約 10 日間経過観察し たが著変はなかった，患児は全く自覚症状を訴之 なかったが，放置すれば突然死を起こす可能性が あると考之，家族の承諾を得て全身麻酔下で QRS 同期型の電気的徐細動 (60ワット)を行い洞調律に 復した。その後はジゴキシンを経口で予防投与し， 3 E可として経過観察している。

症例 3 ：R. O., 6 歳, 女児

特に自覚症状もなく, 元気であった。昭和 57 年

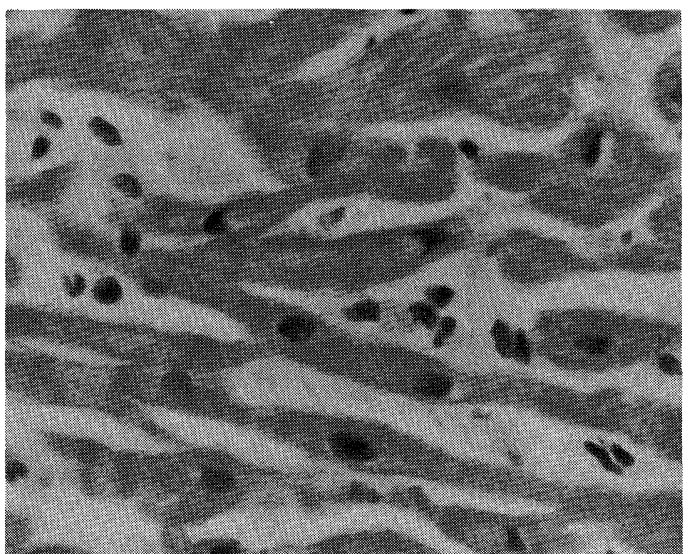

図8Ａ～症例 4 の心内膜心筋生検組織像 $\mathrm{HE}$ 染色 $\times 400$

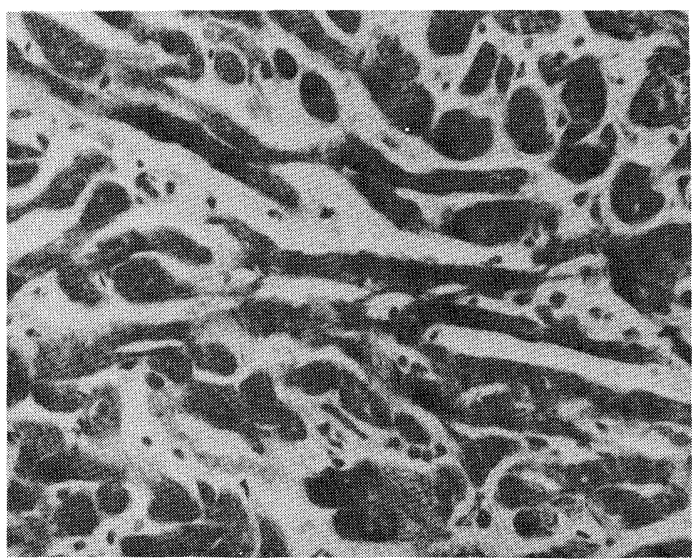

図 8 B

Azan 染色 $\times 100$

度の集団心臟検診で散発性の心室性期外収縮

（VPC）を指摘され来院した。負荷心電図では VPCの増加や short run は認めなかったが, Holter心電図で 2 度にわたる心拍数 150 / 分の心室性 頻拍症が出現していた (図6). 現在，管理区分 3 一Dとして管理している.

症例 4 ：W. I., 12歳, 男児

今までに特記すべき既往歴はない。昭和 57 年度 の集団心臟検診にて初めて心電図異常を指摘され 精査の目的で入院した。現症上では特に異常はな かった。血液一般検查および胸部X線では異常所 見はなかったが, 心電図ではII, III, aVFおよびV $V_{1}$ 


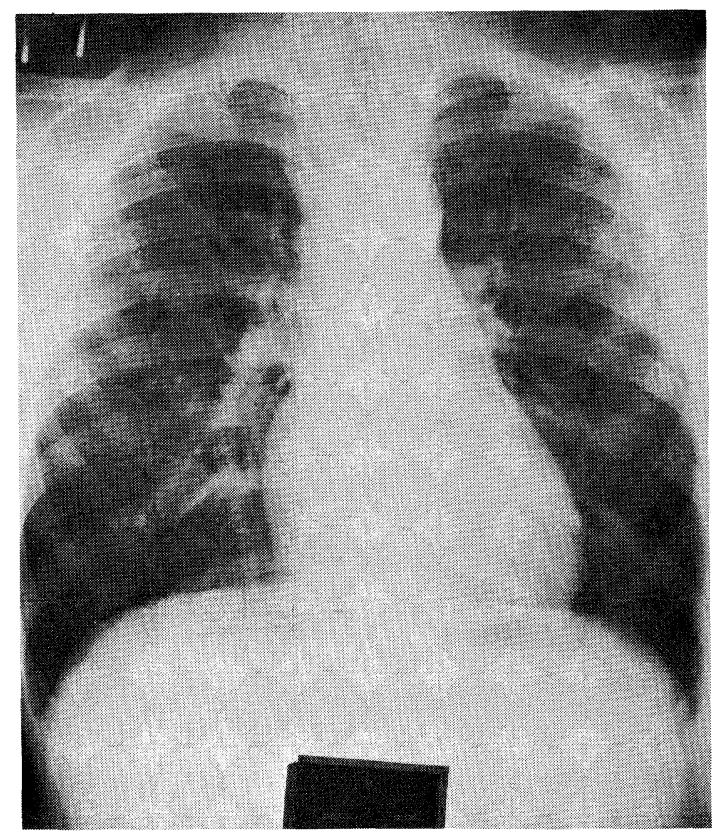

図 9 A 症例 5 の胸部 X線 正面

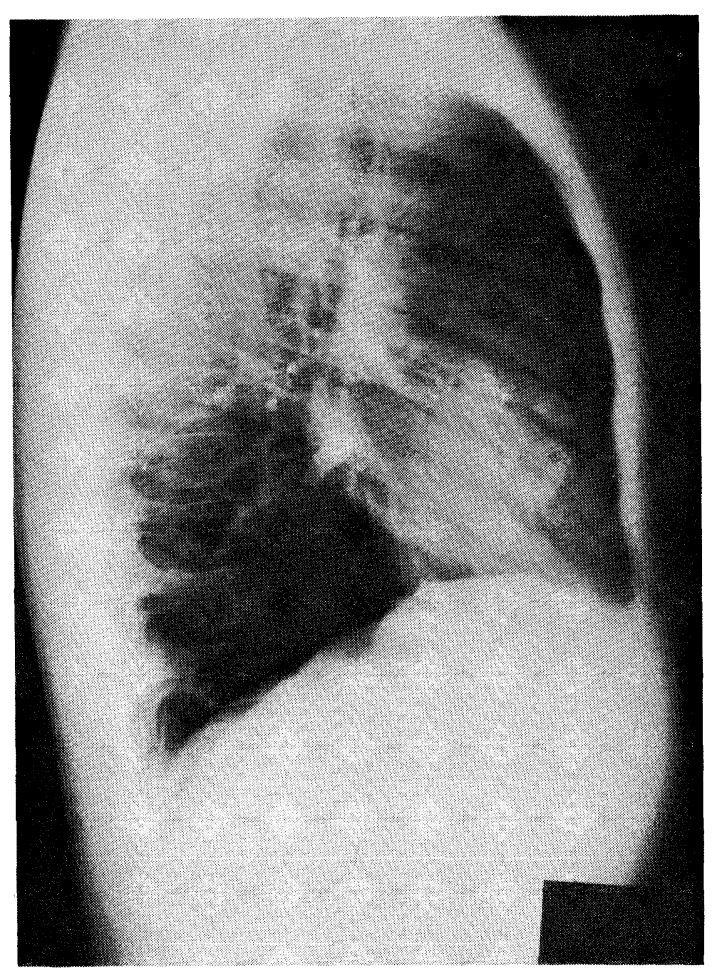

図 9 B

側面
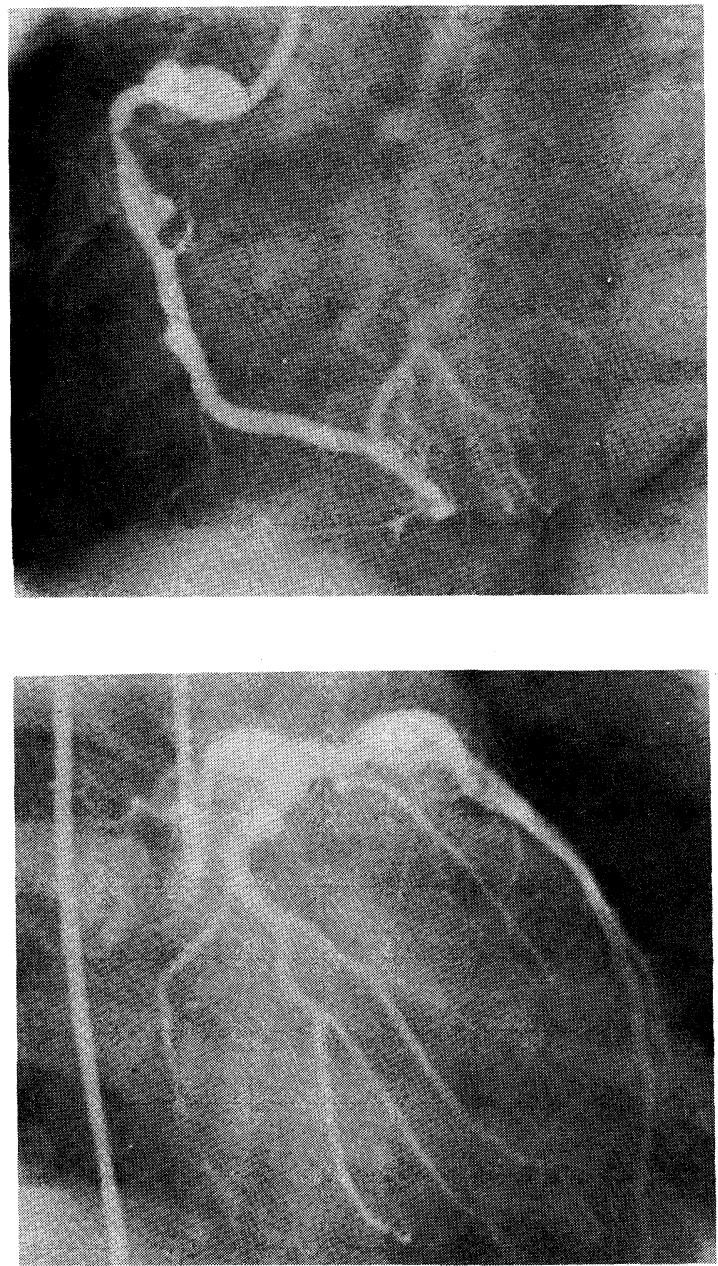

図10 症例 5 の選択的冠動脈造影

上段：右冠動脈

下段：左冠動脈

の異常Q波， ST・T波の上昇， I, a VLでのST・T 波の低下を認めた(四 7 )。出藏超音波検査では心 室中隔（特に心尖部）の非対称性中隔肥大を認め, 心尖部肥大型心筋症と診断した。心血管造影では 左室駆出分画 0.67 と正常であり，心尖部中隔の肥 厚を認めた。同時に行った存心等心内膜心筋生検 では著明な心筋細胞の錯綜配列，変性および肥大 を垫め，又心筋の間質の線維化が軽度に認められ た(网 8)。組織学的には心筋炎後心把大も否定で きなかったが, 臨床的には肥大型心筋症として現 
在，インデラール $20 \mathrm{mg} /$ 日を経口投与し， 2 C可と

して管理している.

症例 5 : Y. I., 10歳, 男児

2 歳 3 ケ月時に川崎病に罹患し, 某大学病院に 入院したことがある。経過は順調であったため, 退院後は無投薬で 1 年間管理されていたが，心臟 超音波検査や心血管造影は一度も行われなかった。 昭和 56 年度の集団心臟検診にて胸部X線上の石灰 化像を認めたため精查の目的で入院した。安静時 およびマスター 2 段負荷心電困では異常はなかっ た。胸部 X 線は, 正面像では不明瞭であったが, 側面像で明瞭な石灰化を認めた(図 9 ). 入院後に 行われた選択的冠動脈造影で, 右冠動脈の $90 \%$ およ び50\%狭窄と左右の多発性の動脈瘤を認めた（図 10). 患児は現在, アスピリン $5 \mathrm{mg} / \mathrm{kg} /$ 日を投与さ れ, 管理区分 $2 \mathrm{C}$ 可として経過観察されている.

以上の症例は日常生活で自覚症状を訴えず聴診 上でも異常所見に之しいため選別方式で抽出され ることが困難であると思われた。また，いずれの 症例も突然死につながる疾患であり，早期発見し 適切な治療および管理が必要であると考えられる。
従って選別方式はこれらの臨床的に極めて重要な 症例を見逃す可能性が高く，その意味では全員心 音・心電図方式が実施されることを望む.

\section{ま と め}

過去10年間の足立区における学童心臓検診の成 績を述べ注目すべき症例を呈示した。これらの症 例が示すように今後は全ての地区で全員心音・心 電図方式が実施されることを望みたい.

ご校閲をいただいた加藤英夫名誉教授に深謝します、 また検診にご協力を頂いた小児科，胸部外科及び循環 器内科の諸先生方とご指導をいただいた東京医科歯科 大の保崎純郎助教授に深謝します。

\section{文献}

1 ) 大国真彦：学童心臟病検診の最近の動向。東京都 予防医学協会年報, $12 ： 9 \sim 16,1981$

2 ) 保崎純郎：東京地区における心臟検診の進歩と昭 和56年度の検診成績. 東京都予防医学協会年報, 12 ： $16 \sim 25,1981$

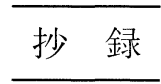

\section{女性生殖路の内分泌細胞}

Endocrine cells in the female genital tract

F. Fetissof, G. Berger, M. P. Dubois., et al.

Histopathology : 9, 133-145, 1985.
内分泌細胞は, 副尿道管腺, バルトリン腺, 子 宮内膜腺，そして中腎由来組織内に正常に存在す る.これら全ての細胞は, セロトニン貯蔵細胞と して特徵づけられる。副尿道管腺やバルトリン腺 ではセロトニン含有細胞は外分泌腺の移行上皮中 に最も高頻度に認められる。

内分泌細胞は, いくつかの病的状態に関与して いた，豊富な嗜銀性細胞は慢性バルトリン腺炎に おいて, 終末腺管内に認められ, セロトニン貯蔵 細胞は固有の子宮頸外膜上皮に認められる。多数
のセロトニン貯蔵細胞は，Peutz-Jeghers 症候群 の患者に発生した高分化型腺癌に認められた。好 銀性細胞は子宮内膜癌の症例に認められた。目立 った特徵は, 珍しい型の子宮内膜腺癌に消化管ぺ プチドホルモンが証明されたことである.

最後に, セロトニン貯蔵細胞は Brenner 腫瘍の 構成成分であった．類似の内分必パターンは， ミ ユラー管と泌尿生殖洞の両者に㫙来する組織が共 有していることが示唆された。

(病理学第一講座 高木由紀) 